\title{
Department of Economic and Mining Geology
}

\author{
Jacek Mucha
}

\section{INTRODUCTION}

The Department of Economic and Mining Geology in its current form was set up in 2006, after the reorganization the Faculty of Geology, Geophysics and Environmental Protection. The department consists of five research groups (units):

1) Economic Geology,

2) Coal Geology,

3) Salt and Chemical Material Deposits,

4) Rock Raw Materials,

5) Mining Geology.

Currently, a total of 21 scientists (including 2 full-time professors and 2 associate professors) are employed in the Department, and 10 graduate students are preparing their $\mathrm{PhD}$ theses. In the last decade, the Department of Economic and Mining Geology was directed by:

- Professor Adam Piestrzyński (until 2008),

- associate Professor Stanisław Majewski (20082012),

- associate Professor Jacek Mucha (2012-2016).

\section{RESEARCH AREAS/ RESEARCH GROUPS}

The Economic Geology Research Group specializes in exploration geology (planning, fieldwork, analysis and interpretation), assessment of already operating deposits and other exploration projects. The group also provides analyses of ore/waste material, including mineralogy and chemical interpretation.

The Coal Geology Research Group concentrates on the petrology of lignite, bituminous coal, anthracites and associed rocks (e.g. bentonites, tonsteins), technological quality of coal, geochemistry of trace elements, lithology and origins of coal seams, coal gasification technology, assessment of coal rank and kerogen thermal maturity, influence of the coal mining industry on the environment, thermal history of sedimentary basins, burial and thermal maturity modelling.

Staff of the of the Rock Raw Materials Research Group focuses essentially on prospection of common mineral materials: building stone (including dimension and cladding stone), rock fill, armourstone and aggregates. All stages of the prospection are carried out: from field surveys, through laboratory testing, to petrographic interpretation and evaluation according to European standards. Both, 'classical' field methods (mapping, logging, and sampling) and IT supported tools (GIS, Remote Sensing) are applied. Furthermore, behavior of the stones in historical buildings and their interaction with polluting agents are studied and practically applied (including protection treatment methods and materials). The history of the application of a stone in buildings is another scope of the Department's research.

The Mining Geology Research Group carries out research activities and performance projects, as well as other assignments obtained from industry and other Polish and foreign institutions within the field of applied mining geology. The scientific and research activities of the Mining Geology Group concern the following problems: exploration of mineral deposits for mining purposes, reporting of mineral deposits exploration results, estimation of mineral resources and mineral reserves and their classification, optimization of mineral deposits sampling, exploration of tailings dumps for their potential use, application of geostatistical and statistical methods for optimizing drilling patterns, planning and designing of geological works, mathematical modelling of mineral deposits, legal issues connected with exploration of mineral deposits and mineral resource exploitation. 


\section{FACILITIES}

The Economic Geology Research Group is equipped with a reflected and light transmitting laboratory, with a digital imaging analysis system and fluid inclusion equipment. A fully equipped 3D computer modelling laboratory is also available.

The Rock Raw Materials Group is equipped with approved testers of mechanical properties of stone and aggregates (compressive strength, modulus of rupture, water sorption, density, frost resistivity, sonic velocity etc.). Optical (microscopic) petrographic analyses form the basis for all stone testing. Computer-based image analysis and measurement systems are applied as standards. Modern and continuously upgraded GIS and RS software and peripherals are applied for advanced spatial and spectral analyses.

The Mining Geology Research Group is equipped with computers and specialized software (e.g. Isatis, Statistica, Corel Draw, Rockworks, Surfer) that make it possible to solve a wide spectrum of problems. Isatis software offers application of proven geostatistical technics for in-depth data analysis, estimation, simulations, mapping, 3D modelling and uncertainty quantification.

\section{EDUCATION AND TEACHING OFFERS}

The Economic Geology Department offers Master's course (in Polish and English) for students with a BSc in geology. Students gain knowledge of exploration processes, methods and strategies applied for different deposit types. Advanced knowledge on mineral deposits (processes, genetic types, mineralogy) is obtained. Students also learn to prepare exploration reports, apply for prospecting licenses and prepare prefeasibility studies. Using advanced software, students gain knowledge on GIS and 3D deposit modeling, with elements of geostatistics and reserve calculations. Additionally, students learn the basics of mining engineering, mineral processing and geometallurgy.

Most of the courses of Rock Raw Minerals is related to the main field of the Research Group's scientific interest, including: economic geology, mineralogy and petrography of rock raw materials,
GIS and Remote Sensing, sustainable exploration and use of stone in its deposits, application and conservation of the stone in architecture.

The Mining Geology Research Group offers a Master's course in the frame of the Mining Geology specialization. Students gain knowledge of geological reporting, prefeasibility studies, geological and mining law, sampling and mapping of deposits, statistical and geostatistical resources, reserve estimation and categorization and 2D and 3D mathematical modelling of deposits. Additionally, the research group of Mining Geology runs postgraduate studies in mining geology.

\section{COOPERATION}

The Department of Economic and Mining Geology actively cooperates with domestic and offshore scientific centres and economic entities.

The partners of the Economic Geology Research Group include: KGHM Polska Miedź SA, KGHM International, ZGH Bolesław, Re Alloys, Trepça under AKP Administration, Kosovo Mining Group, Slovenská banská spol. s.r.o., Geoexpert, Bayajajtatu Mongolia, Polska Akademia Nauk, Kryvyi Rih National University, Instytut Metali Nieżelaznych w Gliwicach, Państwowy Instytut Geologiczny - Państwowy Instytut Badawczy, KGHM CUPRUM sp. z o.o. Centrum Badawczo-Rozwojowe, Uniwersytet Szczeciński, The Bulgarian Academy of Sciences, the University of Athens, University of Salzburg, University of Mitrovica, Comenius University in Bratislava, Matej Bel University of Banská Bystrica, Aristotle University of Thessaloniki, Ivan Franko National University of Lviv, University in Ivano-Frankivsk, University in Leoben, the Geological Survey of the Federation of Bosnia and Herzegovina, Slovak Academy of Sciences, International Committee for Coal and Organic Petrology (ICCP), The Society for Organic Petrology (TSOP), VSB University of Technology (Ostrava), University of Gottingen (Germany), Wydział Górnictwa i Geologii Politechniki Śląskiej in Gliwice, Państwowy Instytut Geologiczny in Warsaw, Państwowy Instytut Geologiczny Oddział Górnośląski, Instytut Nauk Geologicznych PAN, Kraków, Zakład Karbochemii Polskiej Akademii Nauk 
in Gliwice, University of Silesia, Faculty of Earth Sciences in Sosnowiec.

Among the scientific and industrial past and presents partners of the Rock Raw Materials Research group domestic and foreign universities can be found (i.a. in Germany, UK, Italy, Laos, Thailand), the European Commission, governmental agencies (Geologische Bundesanstalt in Vienna), local government bodies and commercial enterprises of various scale; such as mining companies, stone importers, stone conservation workshops etc.

The Mining Geology Research Group carries out research activities and performance projects, as well as other orders obtained from industry and Polish and foreign institutions, within the field of applied mining geology (Lhoist, Lafarge, Interoceanmetal Joint Organization, Marathon SA Australia, KGHM Polska Miedź SA). 